\title{
Evaluation of Baby Corn Hybrids Productivity and Profitability under Different Fertilizer Doses and Spacings
}

\author{
Hargilas \\ Agricultural Research Station (MPUAT), Borwat farm, Banswara, Rajasthan (327 001), India
}

\section{Article History}

Manuscript No. AR1384

Received in $13^{\text {th }}$ May, 2015

Received in revised form $28^{\text {th }}$ July, 2015

Accepted in final form $6^{\text {th }}$ August, 2015

\section{Correspondence to}

"E-mail: hargilasm73@gmail.com

\section{Keywords}

Baby corn, fertilizer dose, spacing, yield, $\mathrm{B}: \mathrm{C}$ ratio

\begin{abstract}
A field experiment was conducted during kharif season of 2014 at Agricultural Research Station, Banswara (MPUAT), Rajasthan in split-split plot design having two fertilizer doses (150:50:60 and 200:60:80 kg of $\left.\mathrm{N}: \mathrm{P}_{2} \mathrm{O}_{5}: \mathrm{K}_{2} \mathrm{O} \mathrm{ha}^{-1}\right)$ in main plots and two plant spacing viz. $60 \times 20 \mathrm{~cm}^{2}$ and $60 \times 15 \mathrm{~cm}^{2}$ in sub plots, while 4 hybrids (Vivek hybrid-27, HM-4, Seed Tech-2524 and HQPM-4) sown in sub-sub plots with three replications. Results revealed that spacing of $60 \times 15 \mathrm{~cm}^{2}$ and 200:60:80 kg NPK ha-1 significantly increased the plant height, green fodder yield, green ear yield with husk and without husk of hybrids over $60 \times 20 \mathrm{~cm}^{2}$ and 150:50:60 $\mathrm{kg} \mathrm{NPK} \mathrm{ha}^{-1}$, respectively. Seed Tech2324 produced significantly maximum green ear yield (121.52 $\left.\mathrm{q} \mathrm{ha}^{-1}\right)$ and dehusked cobs weight (20.13 q ha ${ }^{-1}$ ) over HM 4 (65.93 and $12.32 \mathrm{q} \mathrm{ha}^{-1}$ ), Vivek hybrid-27 (83.65 and $15.80 \mathrm{q} \mathrm{ha}^{-1}$ ) and HQPM-4 (114.73 and $19.22 \mathrm{q} \mathrm{ha}^{-1}$ ), respectively. The maximum green fodder yield ( $\left.244 \mathrm{q} \mathrm{ha}^{-1}\right)$ obtained with Vivek hybrid-27 and was significantly 38.64, 22.00 and 8.44\% higher than HM 4 (176 q ha-1), Seed Tech $2324\left(200 \mathrm{q} \mathrm{ha}^{-1}\right)$ and HQPM-4 (225 q ha-1), respectively. The maximum green ear yield ( $\left.22 \mathrm{q} \mathrm{ha}^{-1}\right)$ of Seed Tech-2324 and fodder yield (283q ha-1) of Vivek hybrid-27 while, B: C ratio (3.49) of HQPM-4 was found with the interaction of $60 \times 15 \mathrm{~cm}^{2}$ and 200:60:80 kg NPK ha-1.
\end{abstract}

\section{Introduction}

Baby corn is the newest introduction and gaining popularity in peri-urban area of the country. Because, it is a dual purpose crop which provides green ears for human consumption and fodder for livestock within 45-60 days after sowing. Being short duration crop, green ears of plant are harvested before pollination within 45-60 days after sowing and it is to be sown and harvested 3-4 times in a year (GOI, 2007). Baby corn is grown for its young, fresh, finger like green ears, harvested at the time of silk emergence and before pollination and fertilization and its ideal size is $5-10 \mathrm{~cm}^{2}$ long and $0.85-1.70$ $\mathrm{cm}$ diameter used as vegetables, salad, soup, pakora, chutney, cutlet, chat, kofta curry, pickle, jam, murabba and other favorite dishes from different hotels and restaurants in the world and the remaining biomass obtained after harvesting green ear is used as excellent green fodder and feed for animal (Dass et al., 2009). The animal productivity directly depends on the availability of good quality green fodder. At present, the country faces a net deficit of $35.6 \%$ of green fodder, $26 \%$ of dry-crop residues and $41 \%$ of concentrate feed ingredients (ICAR, 2013). To overcome this problem, there is a need to shift from sole food and fodder crops to the dual or multipurpose food cum fodder crops. Under this situation, baby corn can be a good option as a dual purpose food cum fodder crop that can maintain the supply of fodder to the burgeoning livestock population of the country (Dhar et al., 2014). The plant enters into the reproductive phase within 45-55 days after sowing and being a short-duration crop (60-70 days). Therefore, it offers intensive rotation cultivation in a system for promoting economic and poverty alleviation in peri-urban area of the country. Among the different agronomic practices, nutrient management, plant density and hybrids are most important factor for determining yield and other agronomic attributes of the crop. The nutrient requirement is very high and the importance of nutrient ( $\mathrm{N}, \mathrm{P}$ and $\mathrm{K})$ in maize becomes even more relevant when it is grown as baby corn because of its high density and very short duration. Hybrids are tested for baby corn to produce more number of green ears plant ${ }^{-1}$ as well as green fodder in short duration with response to nutrient and density. Keeping all these views, the present experiment was conducted to evaluate the yield potential of new hybrids at the economic fertilizer dose and optimum plant spacing under the 
humid southern zone of Rajasthan.

\section{Materials and Methods}

A field experiment was conducted during the rainy season of 2014 at Agricultural Research Station (MPUAT), Borwat farm, Banswara (Rajasthan) located at $23^{\circ} 33^{\prime} \mathrm{N}$ latitude, $74^{\circ} 27^{\prime}$ E longitude and altitude of $220 \mathrm{~m}$ above sea level. The experiment was laid out in split-split plot design with two fertilizer doses of 150:50:60 kg and 200:60:80 kg NPK $\mathrm{ha}^{-1}$ in main plots and two plant spacing of $60 \times 20 \mathrm{~cm}^{2}(83,333$ plants ha-1) and $60 \times 15 \mathrm{~cm}^{2}(1,11,111$ plants ha-1) in sub-plots, while four hybrids of Vivek hybrid-27, HM-4, Seed Tech2524 and HQPM-4 in sub-sub plots with three replications. The soil of experimental field was clay loam in texture with a $\mathrm{pH}$ value of 8.2 , having $0.54 \%$ organic carbon, $206.5 \mathrm{~kg} \mathrm{ha}^{-1}$ available nitrogen, $20.85 \mathrm{~kg} \mathrm{ha}^{-1}$ available phosphorus and 396 $\mathrm{kg} \mathrm{ha}^{-1}$ potassium. The entire dose of phosphorus and potash and $1 / 3$ dose of nitrogen was applied as basal dose in furrow through the tractor drawn fertilizer drill. The remaining dose of nitrogen was applied equally in two splits at 25 and 45 days after sowing (DAS). Ten plants were tagged randomly from each plot for recording of growth and yield attributes. Green ears were harvested immediately within $24 \mathrm{hrs}$ after silk emergence, counted and weighed. Thereafter, husk and silk of cobs were removed. Physical parameters of baby corn like husk and de-husked ear weight recorded every time of harvesting whereas, growth parameters like crop growth rate (CGR) was calculated by using formulae $\left[\mathrm{CGR}=\left(\mathrm{W}_{2}-\mathrm{W}_{1}\right) /\left(\mathrm{T}_{2}-\mathrm{T}_{1}\right)\right]$ given by Fisher (1981) and dry matter accumulation plant ${ }^{-1}$ recorded at 30 and 50 DAS and plant height $(\mathrm{cm})$ and leaf area index (LAI) were recorded at final harvesting of green ears. The green ears yields with husk and without husk were calculated by adding the yield from total harvesting of cobs. The crop was harvested after final harvesting of green ears for green fodder and recorded the green fodder yield. Economic returns were calculated based on price of baby corn without husk (₹ $20 \mathrm{~kg}^{-1}$ ) and green fodder ( $₹ 200 \mathrm{q}^{-1}$ ). Statistical analysis of the recorded data for each character was done using the standard procedures for split-split plot design as suggested by Gomez and Gomez (2010).

\section{Results and Discussion}

\subsection{Growth parameters}

Growth parameters viz., plant height, dry matter accumulation and leaf area index influenced by fertilizer doses, spacings and hybrids (Table 1). Maximum plant height $(196 \mathrm{~cm})$ obtained with fertilizer dose of 200:60:80 $\mathrm{kg}$ NPK ha-1, which was significantly superior over 150:50:60 $\mathrm{kg} \mathrm{NPK} \mathrm{ha}^{-1}$ by $4.3 \%$. Similarly, significantly more plant height $(194.6 \mathrm{~cm})$ was recorded with $60 \times 15 \mathrm{~cm}^{2}$ and was $2.8 \%$ more than spacing of
$60 \times 20 \mathrm{~cm}^{2}\left(1.0\right.$ lac plant ha $\left.{ }^{-1}\right)$. Among the hybrids, maximum plant height $(200 \mathrm{~cm})$ was observed with HM-4, which was not differed with HQPM-4 and was significantly superior over Vivek hybrid-27 and seed Tech-2334, by 7.35 and $9.89 \%$ respectively.

The interaction effect of fertility and spacing on plant height of hybrids found significant (Table 2). The maximum plant height $(197 \mathrm{~cm})$ was observed with 200:60:80 kg NPK ha-1 at $60 \times 15 \mathrm{~cm}^{2}$ which was significantly $7.2 \%$ superior over 150:50:60 kg NPK ha-1 with spacing of $60 \times 20 \mathrm{~cm}^{2}$. Plant height of all hybrids was significantly influenced by fertilizer doses. HQPM-4 recorded the maximum plant height $(204 \mathrm{~cm})$ with 200:60:80 kg NPK ha-1 which was found significantly $3.4-13.7 \%$ higher over HM-4 and seed tech-2524 to 150:50:60 $\mathrm{kg}$ NPK ha-1 ${ }^{-1}$, respectively. Plant height of hybrids increased in $60 \times 15 \mathrm{~cm}^{2}$ but found no significant over spacing of $60 \times 20 \mathrm{~cm}^{2}$. The interaction effect of fertilizer doses, spelling on hybrids was found significant. The maximum plant height $(205 \mathrm{~cm})$ recorded with HQPM-4 at $60 \times 15 \mathrm{~cm}^{2}$ with 200:60:80 kg NPK $\mathrm{ha}^{-1}$ fertilizer application.

Enhanced plant height of hybrids was due enhanced growth of crop through synthesizing more protein and chlorophyll and phosphorus enhances the photosynthesis, energy store and transfer, cell division and enlargement and it is noted especially major role for capturing and converting the sun's energy into useful plant compounds and potassium is required

Table 1: Effect of fertilizers, spacing and hybrid on plant height $(\mathrm{cm})$, leaf area index (LAI) and crop growth rate (CGR) of baby corn

\begin{tabular}{|c|c|c|c|}
\hline Treatment & $\begin{array}{c}\text { Plant } \\
\text { height }(\mathrm{cm})\end{array}$ & LAI & $\begin{array}{c}\text { CGR }\left(\mathrm{g} \mathrm{m}^{-2} \text { day }^{-1}\right) \\
\text { at }(30-50 \text { DAS })\end{array}$ \\
\hline \multicolumn{4}{|c|}{ Fertilizer dose $\left(\mathrm{N}: \mathrm{P}_{2} \mathrm{O}_{5}: \mathrm{K}_{2} \mathrm{O} \mathrm{kg} \mathrm{ha}^{-1}\right)$} \\
\hline $\mathrm{F}_{1}: 150: 50: 60$ & 187.60 & 5.12 & 18.63 \\
\hline $\mathrm{F}_{2}: 200: 60: 80$ & 196.00 & 5.31 & 22.63 \\
\hline $\mathrm{SEm} \pm$ & 0.83 & 0.03 & 0.15 \\
\hline $\mathrm{CD}(p=0.05)$ & 3.90 & 0.16 & 0.70 \\
\hline \multicolumn{4}{|l|}{ Plant spacing } \\
\hline $\mathrm{S}_{1}: 60 \times 20 \mathrm{~cm}^{2}$ & 189.10 & 5.32 & 18.04 \\
\hline $\mathrm{S}_{2}: 60 \times 15 \mathrm{~cm}^{2}$ & 194.60 & 5.11 & 22.62 \\
\hline $\operatorname{SEm} \pm$ & 0.83 & 0.03 & 0.15 \\
\hline $\mathrm{CD}(p=0.05)$ & 3.90 & 0.16 & 0.70 \\
\hline \multicolumn{4}{|l|}{ Hybrid } \\
\hline $\mathrm{V}_{1}$ :Vivek hybrid-27 & 186.30 & 5.44 & 23.20 \\
\hline $\mathrm{V}_{2}: \mathrm{HM}-4$ & 200.00 & 4.80 & 17.43 \\
\hline $\mathrm{V}_{3}:$ Seed Tech-2324 & 182.00 & 5.26 & 19.05 \\
\hline $\mathrm{V}_{4}: \mathrm{HQPM}-4$ & 199.00 & 5.36 & 21.64 \\
\hline $\mathrm{SEm} \pm$ & 1.65 & 0.07 & 0.29 \\
\hline $\mathrm{CD}(p=0.05)$ & 5.5 & 0.23 & 0.98 \\
\hline
\end{tabular}


for numerous plant growth processes such as increase root growth and improves drought resistance and builds cellulose and reduces lodging in plant. It helps to increase the plant height and other growth parameter due to greater availability of nutrients at higher fertilizer doses reported by Sobhana et al. (2012) and similar results were also reported by Thakur et al. (1997) with the increased the rate of nitrogen. Plant density is very important in particular baby corn, because it does not have tillering capacity to adjust for variation in plant stand. Optimum plant density leads to proper utilization of solar radiation which influences leaf area interception and utilization of solar radiation and consequently corn dry matter accumulation and biomass production (Ramachandrappa et al., 2004). The variation observed among the hybrids was mainly due to varietal characters. The result was collaborated with Sahoo (2011) who reported significant variation in plant height of varieties of baby corn.

Dry matter accumulation in hybrids was significantly influenced with fertilizer doses. Maximum dry matter (121.89 g plant ${ }^{-1}$ ) was observed at the higher dose of fertility which found significantly superior to $150: 50: 60 \mathrm{~kg} \mathrm{NPK} \mathrm{ha} \mathrm{h}^{-1}$. Dry matter accumulation increased with high dose of fertility might be due to higher plant height. Crop growth rate (CGR) and leaf area index (LAI) were found significantly higher with 200:60:80 kg NPK ha-1 and $60 \times 15 \mathrm{~cm}^{2}$. Similar findings were reported by Dar et al. (2014).

\subsection{Yield attributes and yield}

Plant population, baby corn yield with husk and without husk and green fodder were influenced by fertilizer doses, spacings and hybrids (Table 3 ). Significantly $20.63 \%$ higher plant population ha ${ }^{-1}$ were observed in high density planting of $1,11,000$ plants ha- $\mathrm{a}^{-1}$ under $60 \times 15 \mathrm{~cm}^{2}$ plant spacing followed by 83,333 plants ha- ${ }^{-1}$ under $60 \times 20 \mathrm{~cm}^{2}$ plant spacing. There was marginal increased in final plant population with 200:60:80 kg NPK ha- ${ }^{-1}$ compared to 150:50:60 $\mathrm{kg} \mathrm{NPK} \mathrm{ha}^{-1}$. The plant population varied with hybrids at harvest. The maximum plant population (93100 plant ha $^{-1}$ ) was observed in Seed Tech-2324 followed by HQPM-4 which found significantly superior over HM-4 and Vivek hybrid-27. The variation in plant population with hybrids, it may caused to germination as well as plant survival percentage of hybrids.

Baby corn yield with husk and without husk significantly increased with fertilizer doses. The maximum green ears (with husk) obtained $99.46 \mathrm{q} \mathrm{ha}^{-1}$ with 200:60:80 $\mathrm{kg} \mathrm{NPK} \mathrm{ha}^{-1}$ and was significantly $6.0 \%$ higher than $150: 50: 60 \mathrm{~kg} \mathrm{NPK} \mathrm{ha}^{-1}$. The spacing of $60 \times 15 \mathrm{~cm}^{2}$ was produced maximum green ears yield $\left(103.39 \mathrm{q} \mathrm{ha}^{-1}\right)$ that recorded significantly $15.48 \%$ superior over $60 \times 20 \mathrm{~cm}^{2}$ spacing. Among, the hybrids, Seed Tech-2324 produced maximum green yield ears $\left(121.52 \mathrm{q} \mathrm{ha}^{-1}\right)$ which was found significantly $84.31,45.27$ and $5.92 \%$ higher over HM-4, Vive hybrid-27 and HQPM-4, respectively. The effect of fertilizer doses keeps enhancing the baby corn yield. The maximum baby corn yield ( $\left.17.55 \mathrm{q} \mathrm{ha}^{-1}\right)$ obtained with 200:60:80 $\mathrm{kg} \mathrm{NPK} \mathrm{ha}^{-1}$ which was recorded significantly $8.47 \%$ higher yield than 150:50:60 $\mathrm{kg} \mathrm{NPK} \mathrm{ha}^{-1}\left(16.18 \mathrm{q} \mathrm{ha}^{-1}\right)$. The spacing of $60 \times 15 \mathrm{~cm}^{2}$ was also produced significantly $8.47 \%$ higher baby corn yield than spacing of $60 \times 20 \mathrm{~cm}^{2}$. Among the hybrids, the maximum de-husked cob yield (20.13 $\left.\mathrm{q} \mathrm{ha}^{-1}\right)$ recorded with Seed Tech-2324, which was found significantly $63.39,27.40$ and $4.73 \%$ superior over HM-4, Vivek hybrid27 and HQPM-4, respectively. The data showed that both green ears and de-husked cob yield increased significantly with increase in spacing $60 \times 15 \mathrm{~cm}^{2}$ with 200:60:80 $\mathrm{kg}$ NPK ha. This may be attributed to more numbers of cobs resulted higher plant population with better availability of nutrients at higher fertility level (Sobhana et al., 2012). The yield variation in hybrids was also reported by Pandey et al., 2002.

The interaction effect of fertilizer doses and plant spacing on yield of hybrids was found significant (Table 5). The maximum baby corn yield of hybrids $\left(18.19 \mathrm{q} \mathrm{ha}^{-1}\right)$ was recorded with 200:60:80 kg NPK ha-1 at $60 \times 15 \mathrm{~cm}^{2}$ spacing, which was significantly $17.43 \%$ superior over 150:50:60 kg NPK ha-1 and spacing of $60 \times 20 \mathrm{~cm}^{2}\left(15.45 \mathrm{q} \mathrm{ha}^{-1}\right)$. The interaction of fertilizer doses and hybrids was found significant to improve baby corn yield. The maximum baby corn yield $\left(21.03 \mathrm{q} \mathrm{ha}^{-1}\right)$ obtained with Seed Tech-2324 at 200:60:80 kg NPK ha-1 and was statistically at par with HQPM-4 and significantly superior over rest of the interaction combinations of fertility and hybrids. The minimum yield (11.95 q ha $\left.{ }^{-1}\right)$ of HM-4 was observed at 150:50:60 kg NPK ha-1. The similar results were also found by Pandey et al. (2002). The interaction of fertilizer

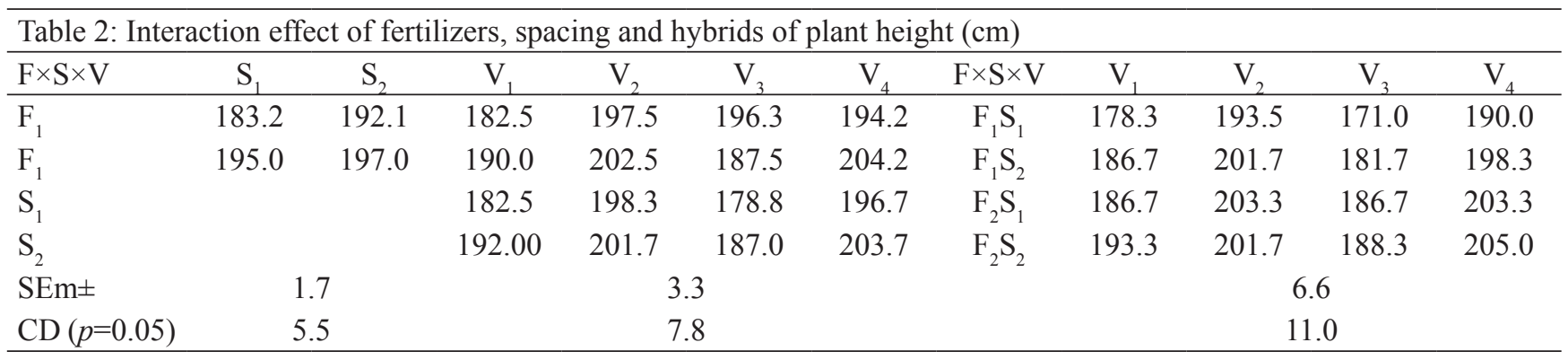


doses and spacing with hybrids was also found significant. Seed Tech-2324 produced maximum baby corn yield $\left(22.00 \mathrm{q} \mathrm{ha}^{-1}\right)$ in $60 \times 15 \mathrm{~cm}^{2}$ spacing at a 200:60:80 kg NPK ha- ${ }^{-1}$ which was recorded significantly superior over rest of the interactions. The minimum yield (11.71 $\left.\mathrm{q} \mathrm{ha}^{-1}\right)$ produced by HM-4 in spacing of $60 \times 20 \mathrm{~cm}^{2}$ at 150:50:60 $\mathrm{kg}$ NPK ha- ${ }^{-1}$.

Table 3: Effect of fertilizers, spacing and hybrids on plant population, baby corn and green fodder yield

\begin{tabular}{lcccc}
\hline Treatment & $\begin{array}{c}\text { Plant } \\
\text { popula- } \\
\text { tion }(000 \\
\left.\text { ha }^{-1}\right) \text { at } \\
\text { harvest }\end{array}$ & $\begin{array}{c}\text { Baby } \\
\text { corn } \\
\text { yield } \\
\text { with husk } \\
\left(\mathrm{q} \mathrm{h}^{-1}\right)\end{array}$ & $\begin{array}{c}\text { Baby } \\
\text { corn yield } \\
\text { without } \\
\text { husk } \\
\left(\mathrm{q} \mathrm{ha}^{-1}\right)\end{array}$ & $\begin{array}{c}\text { Green } \\
\text { fodder } \\
\text { yield } \\
(\mathrm{q}\end{array}$ \\
ha $\left.^{-1}\right)$
\end{tabular}

The green fodder yield influenced by fertilizer dose, plant spacing and hybrids. The maximum green fodder yield $\left(220 \mathrm{q} \mathrm{ha}^{-1}\right)$ obtained with 200:60:80 $\mathrm{kg} \mathrm{NPK} \mathrm{ha}^{-1}$, which was significantly superior over $150: 50: 60 \mathrm{~kg} \mathrm{NPK} \mathrm{ha}^{-1}$ by $8.91 \%$ and similar finding was reported by Singh et al. (2010). The spacing of $60 \times 15 \mathrm{~cm}^{2}$ produced maximum green fodder $\left(227 \mathrm{q} \mathrm{ha}^{-1}\right)$ which was $16.4 \%$ significantly superior over spacing of $60 \times 20$ $\mathrm{cm}^{2}$. Among hybrids, Vivek hybrid-27 produced maximum green fodder yield ( $244 \mathrm{q} \mathrm{ha}^{-1}$ ) which was found significantly superior over HM-4, Seed Tech-2324 and HQPM-4, by 38.64, 22.00 and $8.44 \%$ respectively. The interaction effect of nutrient levels and spacing on green fodder yield was found significant (Table 5). The maximum green fodder yield $\left(238 \mathrm{q} \mathrm{ha}^{-1}\right)$ was obtained with 200:60:80 kg NPK ha-1 at $60 \times 15 \mathrm{~cm}^{2}$ and was found statistically at par with same plant spacing at 150:50:60 $\mathrm{kg} \mathrm{NPK} \mathrm{ha-1}$ and significantly superior over spacing of $60 \times 20$ $\mathrm{cm}^{2}$ at both fertilizer doses. This may be due to high plant population at spacing of $60 \times 15 \mathrm{~cm}^{2}$ and similar results reported by Ramchandrappa et al. (2004). The interaction effect of fertilizer doses and hybrids on green fodder was also found significant. The maximum green fodder yield $\left(257 \mathrm{q} \mathrm{ha}^{-1}\right)$ produced by Vivek hybrid-27 at 200:60:80 $\mathrm{kg}^{\mathrm{NPK}} \mathrm{ha}^{-1}$ and found significantly superior over HM-4, Seed Tech-2324 and HQPM-4 by $40.89,23.20$ and $10.63 \%$ at $200: 60: 80 \mathrm{~kg}$ NPK $\mathrm{ha}^{-1}$ and $11.19,51.72,34.26$ and $17.56 \%$ of $150: 50: 60 \mathrm{~kg} \mathrm{NPK}$ ha $^{-1}$, respectively. Vivek hybrid-27 also produced maximum fodder yield (266 q ha-1) at spacing of $60 \times 15 \mathrm{~cm}^{2}$ which was significantly superior over rest interactions of spacing and hybrids. The interaction effect of fertility, spacing and hybrids was also found significant for fodder production. The maximum green fodder yield $\left(283 \mathrm{q} \mathrm{ha}^{-1}\right)$ produced by Vivek hybrid-27 in spacing of $60 \times 15 \mathrm{~cm}^{2}$ with $200: 60: 80 \mathrm{~kg} \mathrm{NPK}$

Table 4: Interaction effect of fertilizers, spacing and hybrids on baby corn yield (q ha $\left.{ }^{-1}\right)$

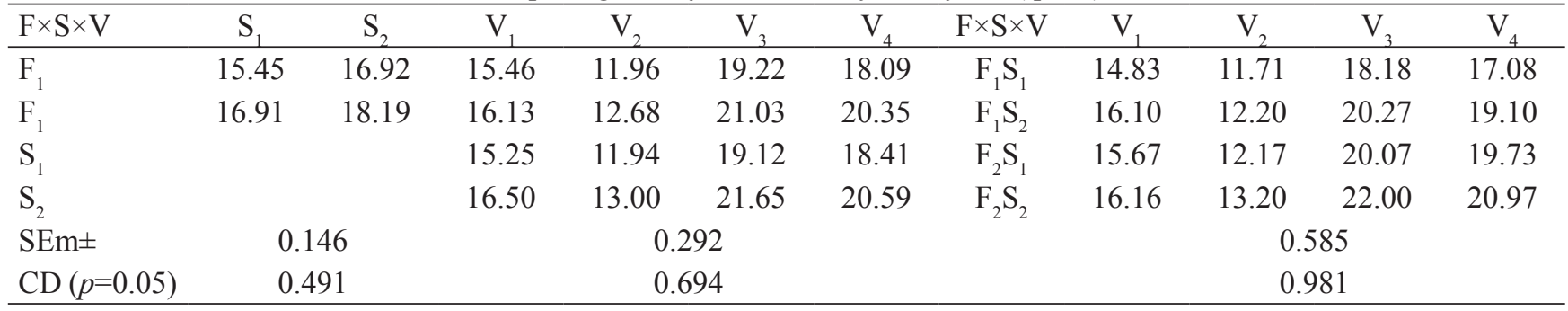

Table 5: Interaction effect of fertilizers, spacing and hybrids on fodder yield (q ha $\left.{ }^{-1}\right)$

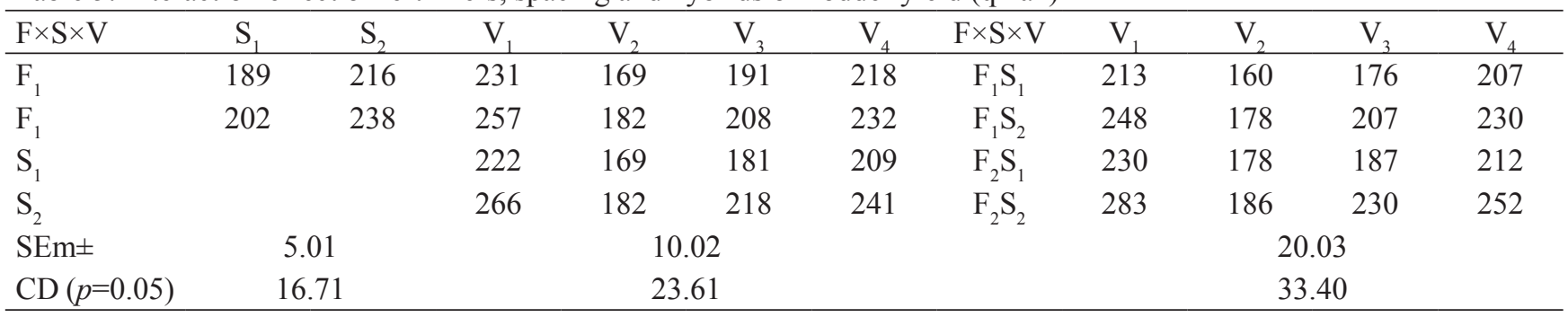


$\mathrm{ha}^{-1}$ which was found statistically at par with HQPM-4 at same plant spacing and fertilizer dose. However, it was significantly superior over HM-4 and Seed Tech-2324 by 52.33 and $23.19 \%$ respectively. Increased yield attributes with increased fertilizer doses and spacing of $60 \times 15 \mathrm{~cm}^{2}$ may be due to application of fertilizers to baby corn maintained greenness of leaves for long periods which in turn helped in greater photosynthesis and assimilation and that might have contribute much as a major source for the development of sink thereby improved the yield attributes (Gosavi and Bhagat, 2009). Significantly the highest green fodder yield was recorded in Vivek hybrid-27 at 200:60:80 kg NPK ha-1 indicating a faster growth under the influence of 200:60:80 $\mathrm{kg} \mathrm{NPK} \mathrm{ha}^{-1}$ with spacing of $60 \times 15 \mathrm{~cm}^{2}$

\begin{tabular}{|c|c|c|c|c|c|}
\hline \multicolumn{6}{|c|}{$\begin{array}{l}\text { Table 6: Effect of fertilizers, spacing and hybrids return from } \\
\text { baby corn and fodder, gross return, net return and benefit: } \\
\text { cost ratio }\end{array}$} \\
\hline Treatment & $\begin{array}{l}\text { Return } \\
\text { from } \\
\text { baby corn } \\
\left(₹ \mathrm{ha}^{-1}\right)\end{array}$ & $\begin{array}{l}\text { Return } \\
\text { from green } \\
\text { fodder } \\
\left(₹ \mathrm{ha}^{-1}\right)\end{array}$ & $\begin{array}{l}\text { Gross } \\
(₹ \\
\left.\text { ha }^{-1}\right)\end{array}$ & $\begin{array}{l}\text { Net } \\
\text { return } \\
(₹ \\
\left.\text { ha }^{-1}\right)\end{array}$ & $\mathrm{B}: \mathrm{C}$ \\
\hline \multicolumn{6}{|c|}{ Fertility level $\left(\mathrm{N}: \mathrm{P}_{2} \mathrm{O}_{5}: \mathrm{K}_{2} \mathrm{O} \mathrm{kg} \mathrm{ha-1}\right)$} \\
\hline $\mathrm{F}_{1}: 150: 50: 60$ & 32368 & 40475 & 72873 & 54242 & 2.91 \\
\hline$F_{2}: 200: 60: 80$ & 35100 & 43958 & 74708 & 58678 & 2.88 \\
\hline $\mathrm{SEm} \pm$ & 147 & 501 & 530 & 530 & 0.025 \\
\hline $\mathrm{CD}(p=0.05)$ & 694 & 2362 & 2501 & 2501 & NS \\
\hline \multicolumn{6}{|l|}{ Plant spacing } \\
\hline $\mathrm{S}_{1}: 60 \times 20 \mathrm{~cm}^{2}$ & 32359 & 39058 & 71417 & 52153 & 2.71 \\
\hline $\mathrm{S}_{2}: 60 \times 15 \mathrm{~cm}^{2}$ & 35108 & 45375 & 76133 & 60768 & 3.08 \\
\hline $\mathrm{SEm} \pm$ & 147 & 501 & 530 & 530 & 0.025 \\
\hline $\mathrm{CD}(p=0.05)$ & 694 & 2362 & 2501 & 2501 & 0.122 \\
\hline \multicolumn{6}{|l|}{ Hybrid } \\
\hline $\begin{array}{l}\mathrm{V}_{1}: \text { Vivek } \\
\text { hybrid-27 }\end{array}$ & 31595 & 48750 & 76695 & 60855 & 3.12 \\
\hline $\mathrm{V}_{2}: \mathrm{HM}-4$ & 24642 & 35133 & 62158 & 40285 & 2.07 \\
\hline $\begin{array}{l}\mathrm{V}_{3}: \text { Seed } \\
\text { Tech-2324 }\end{array}$ & 40257 & 39950 & 80640 & 60717 & 3.11 \\
\hline $\mathrm{V}_{4}: \mathrm{HQPM}-4$ & 38442 & 45033 & 75608 & 63985 & 3.28 \\
\hline $\mathrm{SEm} \pm$ & 294 & 1002 & 1061 & 1061 & 0.051 \\
\hline $\mathrm{CD}(p=0.05)$ & 981 & 3340 & 3537 & 3537 & 0.171 \\
\hline
\end{tabular}

might have played a significant role in reducing competition for photosynthetic and nutrients with each other resulting in healthy plants. The similar findings were observed by Sahoo and Panda (1999); Dar et al. (2014).

\subsection{Economics}

The data for gross and net return and $\mathrm{B}: \mathrm{C}$ ratio presented in table 6 revealed that the return from baby corn at 200:60:80 $\mathrm{kg} \mathrm{NPK} \mathrm{ha-1}$ was found significantly $8.44 \%$ higher than low nutrient level. The spacing of $60 \times 15 \mathrm{~cm}^{2}$ gave significantly $8.47 \%$ higher return than spacing of $60 \times 20 \mathrm{~cm}^{2}$. Among the hybrids, maximum return ( $₹ 40257$ ) obtained from baby corn yield of Seed Tech-2324 which was found significantly superior over HM 4, Vivek hybrid 27 and HQPM 4 by 63.37, 27.42 and $4.72 \%$ respectively.

Gross return from baby corn and fodder yield was not significantly influenced through fertilizer doses and plant spacing (Table 6). Among hybrids, the maximum return (₹ 80640) obtained with Seed Tech-2324 which was found significantly superior by $29.73 \%$ over HM 4 and statistically at par with rest of the hybrids. Net return was directly influenced through fertilizer doses and spacing. The maximum net return (₹ 58678) obtained at the 200:60:80 kg NPK ha-1, which was found significantly $8.17 \%$ higher than $150: 50: 60 \mathrm{~kg} \mathrm{NPK} \mathrm{ha}^{-1}$. The spacing of $60 \times 15 \mathrm{~cm}^{2}$ gave significantly $16.52 \%$ higher net return than spacing of $60 \times 20 \mathrm{~cm}^{2}$. Among hybrids, highest net return (₹ 63985) obtained with HQPM-4 which was found significantly $58.83 \%$ higher than HM-4 and statistically at par with rest hybrids.

The B:C ratio was not significantly varied with different fertilizer doses (Table 6). B:C ratio varied with plant spacing, the maximum $\mathrm{B}: \mathrm{C}$ ratio (3.08) recorded at spacing of $60 \times 15$ $\mathrm{cm}^{2}$ which significantly $13.65 \%$ higher than spacing of $60 \times 20$ $\mathrm{cm}^{2}$. Among hybrids, the maximum B:C ratio (3.28) obtained with HQPM-4 and it recorded $58.45 \%$ higher than HM-4. However, it found statistically at par with rest of the hybrids. The interaction effect of fertilizer doses and spacing was found significant (Table 7). The maximum B:C ratio (3.08) obtained at spacing of $60 \times 15 \mathrm{~cm}^{2}$ with both fertilizer doses which found significantly 15.36 and $12.41 \%$ superior over spacing of $60 \times 20$ $\mathrm{cm}^{2}$ with high and 150:50:60 $\mathrm{kg} \mathrm{NPK} \mathrm{ha}^{-1}$, respectively. The

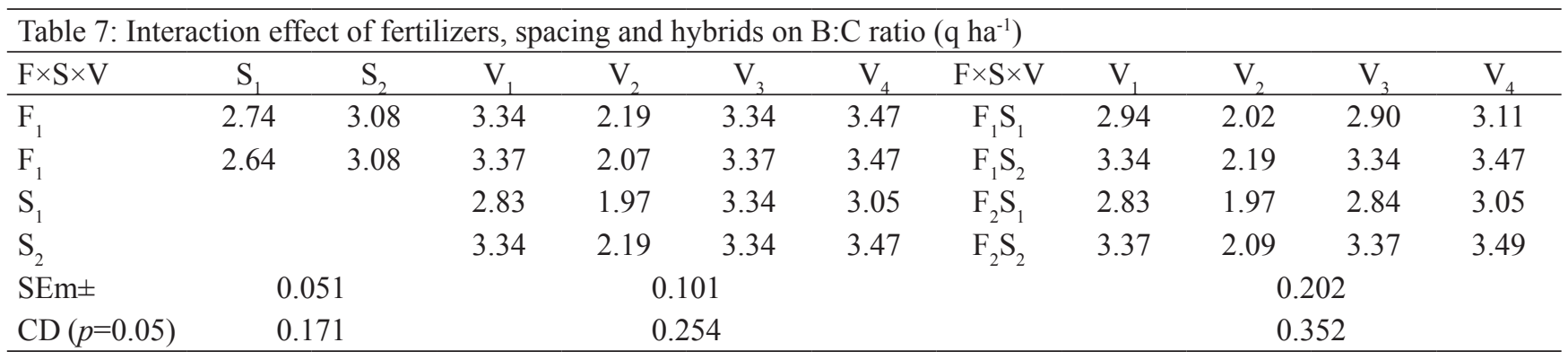


higher economic return and benefit: cost ratio in spacing of $60 \times 15 \mathrm{~cm}^{2}$ may be resulted due to higher yield of baby corn as well as green fodder in spacing of $60 \times 15 \mathrm{~cm}^{2}$ (Dar et al., 2014).The interaction effect of fertilizer doses with hybrids was found significant. The maximum B:C ratio (3.47) obtained with HQPM-1 at both fertilizer doses which was at par with vivek hybrid-27 and seed tech-2324 and significantly superior over HM-4 at both fertilizer dose. This may be attributed to higher yield of green fodder due to higher plant height. The interaction effect of spacing with hybrids was found significant. B: C ratio of all hybrids increased significantly with spacing of $60 \times 15$ $\mathrm{cm}^{2}$ except HM-4. The maximum B:C ratio (3.48) obtained in HQPM-4 at spacing of $60 \times 15 \mathrm{~cm}^{2}$ which found statistically at par with all hybrids and significantly superior over spacing of $60 \times 20 \mathrm{~cm}^{2}$ except HM-4. The maximum B:C ratio obtained 3.49 with HQPM-4 in spacing of $60 \times 15 \mathrm{~cm}^{2}$ at $200: 60: 80 \mathrm{~kg}$ NPK ha-1 which was significantly superior over HM-4 at both plant spacing and fertilizer dose and spacing of $60 \times 20 \mathrm{~cm}^{2}$. However, it was at par with Vivek hybrid-27 and Seed Tech2324 in spacing of $60 \times 15 \mathrm{~cm}^{2}$ at both fertilizer dose.

In this investigation, the net return and $\mathrm{B}: \mathrm{C}$ ratio were not varied significantly with fertilizer doses that might be due to higher cost of fertilizers compared to yield enhancement by nutrients. The similar findings were observed by Pandey et al. (2002); Ramchandrappa et al. (2004). The net return and $\mathrm{B}: \mathrm{C}$ ratio observed significantly higher in spacing of $60 \times 15 \mathrm{~cm}^{2}$ compared to spacing of $60 \times 20 \mathrm{~cm}^{2}$ accordance findings of Thakur et at. (1997) recorded that the higher profits earned with spacing of $60 \times 15 \mathrm{~cm}^{2}$ might be due to higher yield production in closer spacing. The high monetary return was recorded with high yielding hybrids in spacing of $60 \times 15 \mathrm{~cm}^{2}$ might be due high yield obtained per unit area. These similar findings were reported by Nandal et al. (2010).

\section{Conclusion}

Hybrids produced high yield with $60 \times 15 \mathrm{~cm}^{2}$ and 200:60:80 kg NPK ha-1. The maximum green ears yield $\left(22 \mathrm{q} \mathrm{ha}^{-1}\right)$ of Seed Tech-2324 and fodder yield (283 q ha $\left.{ }^{-1}\right)$ of Vivek hybrid-27 and B:C ratio (3.49) of HQPM-4 found with $60 \times 15 \mathrm{~cm}^{2}$ and 200:60:80 kg NPK ha ${ }^{-1}$. However, HQPM-4 is found more profitable than others hybrids at $60 \times 15 \mathrm{~cm}^{2}$ with $200: 60: 80$ $\mathrm{kg}$ NPK ha ${ }^{-1}$ due to higher return from green ear as well as fodder yield.

\section{References}

Dar, E.A., Harika, A.S., Datta, A., Jat, H.S., 2014. Growth, yield and economic return from the dual purpose baby corn (Zea mays) under different planting geometry and nitrogen level. Indian Journal of Agronomy 59, 468-470.
Dass, S., Yadav, V.K., Kwatra, A., Sekhar, J.C., Yadav, Y., 2009. Baby corn production technology and value addition. Project Directorate, Directorate of Maize Research, 46

Fisher, R.A., 1981.Techniques of growth analysis. Annals of Applied Biology 7, 367-72.

Gomez, K.A., Gomez, A.A., 2010. Statistical procedures for agriculture research. Wiley Indian Pvt. Ltd., New Delhi, India.

GOI, 2007. Agricultural statistics at a glance. Directorate of Economics and Statistics, Ministry of Agriculture, Government of India, New Delhi.

Gosavi, S.P., Bhagat, S.B., 2009. Effect of nitrogen levels and spacing on yield attributes, yield and quality parameters of baby corn (Zea mays). Annals of Agricultural Researh $30,125-128$.

ICAR, 2013. DARE/ICAR E-Book, January-March, 2013. www.dare.nic in/nodel/87.

Nandal, J.K., Gupta, V., Pratap, P.S., Tehlan, S.K., 2010. Potential of baby corn cultivation in crop diversification under rice-wheat cropping system. Indian Horticulture 67(Special Issue), 276-278

Pandey, A.K., Mani, V.P., Ved, P., Singh, R.D., Gupta, H.S., 2002. Effect of varieties and plant densities on yield, yield attributes and economics of baby corn (Zea mays L). Indian Journal of Agronomy 47, 221-226.

Ramachandrappa, B.K., Nanjappa, I.I.V., Shivakumar, I.I.K., 2004. Yield and quality of baby corn (Zea mays L.) as influenced by spacing and fertilization levels. Acta Agronomica Hungarica 52, 237-243.

Sahoo, S.C., 2011. Yield and economics of baby corn (Zea mays L.) as affected by varieties and levels of nitrogen. Range management and Agroforestry 32,135-137.

Sahoo, S.C., Panda, M.M., 1999. Effect of levels of nitrogen and plant population on yield of baby corn (Zea mays). Indian Journal of Agricultural Science 69, 157-158.

Singh, M.K., Singh, R.N., Singh, S.P., Yadav, M.K., Singh, V.K., 2010. Integrated nutrient management for higher yield, quality and profitability of baby corn (Zea mays). Indian Journal of Agronomy 55, 100-104.

Sobhana, V., Kumar, A., Idnani, L., Singh, I., 2012. Plant population and nutrient requirement for baby corn hybrids (Zea mays). Indian Journal of Agronomy 57, 294-296.

Thakur, D.R., Prakash, O.M., Kharwara, P.C., Bhalla, S.K., 1997. Effect of nitrogen and plant spacing on growth, yield and economics of baby corn (Zea mays). Indian Journal of Agronomy 42, 479-483. 